\title{
Economic Interests and the Framing of the 1988 and 1992 Democratic and Republican Party Platforms
}

\section{Terri Susan Fine, University of Central Florida}

In this paper, the role that economic groups play in attempting to shape party platforms is examined by analyzing economic group presence at the 1988 and 1992 Democratic and Republican platform writing hearings. Whether the same economic groups participating as witnesses in the platform writing hearings also contributed to the presidential campaigns is also explored.

The findings suggest that economic interest group participation varied widely between 1988 and 1992 and declined across years. Trade associations dominated economic group participation whereas labor unions did not take an active role. Business interests showed a strong preference for the Republicans in 1988 and reasonably equal interest in both parties the following year.

The participatory decline among these groups may be explained by a growing perception that platforms are less effective as campaign guides and policy tools in an era dominated by candidate centered elections, split ticket voting and increasing independent identification, all indicators of decreasing reliance on the parties at the mass and elite levels.

Economic interest groups share an enduring, colorful interplay with political parties. Labor unions, corporations and trade associations are active participants in electoral politics. At times, economic group and political party interactions resemble a partnership whereas other circumstances might suggest an adversarial relationship. One questions economic group-political party dynamics because their relationship will likely continue (Green and Guth 1986). Of particular interest here is the role that economic groups play in attempting to shape party platforms.

Economic groups and political parties perform similar campaign functions such as fund raising, endorsements, volunteer mobilization, "get out the vote" drives and campaign contributions. Labor unions, trade associations and corporations enjoy freedoms that parties do not such as making independent expenditures in federal campaigns, spending money on behalf of any candidate before the nomination is a fait accompli and donating money to candidates from either party giving economic interests advantages over parties in electoral politics.

Unlike the parties, economic interests neither oversee the nomination process nor perform such party functions as election management or nominating conventions (Frantzich 1989). Further, interest group labels do not

TERRI SUSAN FInE is Associate Professor of Political Science at the University of Central Florida.

The American Review of Politics, Vol. 16, Spring, 1995: 79-93

(๑1995 The American Review of Politics 
determine legislative power, political appointments or who rallies for whom during campaigns (i.e., celebrated party members stumping for lesser known colleagues).

One issue or set of related concerns dominates economic group agendas. Speaking to the American public beyond one's agenda is inconsistent with interest group strategy. Political parties, by comparison, communicate with a broad-based constituency in attempting to unify a wide constellation of concerns behind their banner. For labor union, trade association and corporate agendas to be embraced by the party faithful, interest group perspectives must first be communicated by the party to its mass and elite membership. One means to achieve this linkage is with party platforms.

Political party platforms address the policy preferences of the electorate and provide written guidelines for campaigning and governance. Issue coverage in platforms is presented to the electorate in a manner consistent with party views on relevant concerns of the day. Platforms are also the only documents officially adopted by representative delegations of the party faithful (Fine 1991). Writing the platform incorporates democratic procedures by including party members at the framing and adoption stages of the process.

The politics of platform adoption has received little treatment in the scholarly exploration of party platforms. One aspect of the platform writing process is how nonparty groups shape partisan issue positions. Outsiders may communicate with the parties by testifying before the platform committees. As recent findings suggest a strong connection between platform planks and public policy (Budge and Hofferbert 1990; Pomper and Lederman 1980), an exploration of those actors integral to the platform writing process is warranted because outsiders can influence party planks that may later affect policy decisions. Written party promises also serve an accountability function by the mass membership and opposition.

Many witnesses testifying before the platform writing committees represent economic groups. When an economic group perspective is reflected in a platform, its views are being endorsed by that party. What may otherwise be perceived as a specialized, narrowly focused position then becomes party policy. Because platforms provide guidance to candidates and policy direction to office holders, an economic group's perspective is then brought further into the political mainstream. Contributing to the platform affords economic interests an opportunity to influence party agenda setting.

Testifying also serves a symbolic purpose by allowing both group leaders and the parties to foster legitimacy. Outside groups reinforce the perception that they are advancing organizational goals in the political arena whereas the parties demonstrate their openness to outside guidance. The 
symbolic nature of the platform writing process allows one aspect of the interaction between the parties and economic groups to be played out before the public eye.

Participating economic groups may also be those organizations contributing to presidential campaigns. These activities parallel one another because communicating issue perspectives and policy expectations to candidates is the primary goal. At the same time, each activity indirectly affects policymaking. As witnesses, economic groups provide advice; they do not guide proceedings. As contributors, limitations restrict influence between financial assistance and presidential behavior.

Economic group participation in party politics in the present context remains unexplored. This activity will be compared with campaign contribution behavior because a broad literature on that topic already exists. Questioning whether economic groups utilize these same avenues is also warranted due to the goal similarity of each activity.

Economic group testimony patterns before the Democratic and Republican party platform writing committees in 1988 and 1992 is examined herein. Additionally, whether those economic groups testifying contributed money to presidential campaigns that same year is also questioned.

\section{Background Research}

Economic interest participation will be explored using two analytical frameworks. Economic group testimony will be initially compared with campaign contribution behavior and then analyzed within the context of general interest group testimony. A comparison across presidential election years will facilitate an assessment of variation within different competitive circumstances.

\section{Comparing Campaign Contributions with Testimony Patterns}

Donor behavior and testimony expectations are comparable because each requires small individual investments. Federal law restricts PAC donations and traveling to regional platform sessions requires small monetary outlays. Economic interests seek influence by contributing either their dollars or advice.

Further, PAC donations may not foster loyalty from elected officials because individual contributions finance a small portion of the funds necessary to run an effective, technologically sophisticated campaign. By comparison, witnesses receive little testimony time and establishing linkage 
between testimony and platform planks is difficult because factors such as traditional issue positions may predispose party perspectives. ${ }^{1}$

Investigations of corporate PAC giving patterns reveal two dominant views. One perspective suggests that corporate contributions reflect the belief that American business flourishes (see Lindblom 1977) whereas another argues that corporate diversity mirrors giving patterns (labeled "corporate individualism" by Eismeier and Pollock [1988]).

Three individualistic giving strategies are identified. The pragmatic accommodationist emphasizes incumbency because of the favorable electoral climate (Eismeier and Pollock 1988, 28). The adversary hopes that changing the Congressional makeup will lead to an altered policy direction (Eismeier and Pollock 1988, 28). A candidate's competitive situation receives secondary consideration with partisan oriented donations $(1988,28)$. Testimony patterns may follow these approaches because similar motives foster each activity (See also Burris 1987; Handler and Mulkern 1982; Herndon 1982).

PACs may also engage in "double giving" so that neither candidate seeking the same office is offended (Shea and Miller 1989). Similarly, both parties will hear an organization's testimony should it seek assurance that its interests will be heard by the as yet unknown victor.

While platforms communicate party concerns, some argue that platforms serve as presidential campaign documents (Fishel 1985). An economic interest that views the platform accordingly may gear its testimony toward that end (i.e., one seeking a leadership change will appear before the "out" party whereas the "in" party will be chosen should the group desire and/or expect an incumbent victory).

One other factor guiding party choice of party is found in traditional economic group dynamics that are reflected in contribution behavior and legislative evaluations. Historically, Democrats have supported labor whereas Republicans favor big business. These partisan differences are reflected in both contribution behavior and legislative evaluations. Labor PACs tend to support pro-labor candidates and influence labor legislation (Wilhite and Theilmann 1987). Business and labor PACs rate the same members of Congress differently (Hetzner and Westin 1987). Evaluative differences are attributed to goal disparity.

\section{Economic Group Testimony as a Subset of Interest Group Activity}

General interest group behavior also provides an analytical tool for investigating economic group activity. Audience selection may be determined by the perception that party receptivity to group views is reflected in the platform. Fine (1994) identifies four approaches that outline why an 
interest group may choose to appear before one or both parties called "Greater Access," "Power Center," "Even Money," and "Friendly Ear."

Interests who believe that the "out" party will be more receptive to an outsider's perspective will take the "Greater Access" approach. An incumbent president or likely party nominee dictates his concerns to the platform committee (Fishel 1985). Greater influence is achieved with the out party because a dominant incumbent is absent (See also Parris 1972). When a party is out of (presidential) power, interest group advice may more likely be taken because opportunities to guide the process are greater in these parties' nominating conventions. While platforms represent a "trade-off" between the presumed nominee and group interests, group impact is commonly greater without an incumbent force guiding the proceedings (Fishel 1985). Choosing the "out" party is reflected in the adversarial approach among PAC donors.

Those taking the "Power Center" approach will gravitate toward the expected victor. Early in 1988, many predicted that Reagan's strong popular support would facilitate a Republican presidential victory. George Bush's incumbency and association with Reagan created re-election expectations in $1992 .^{2}$ Selecting the Republicans would indicate an interest's desire to communicate with "the powers that be." The "Power Center" approach is comparable to the accommodationist strategy taken by corporate PACs.

Economic principles suggest that preference be granted viable candidates. PACs tend to favor incumbents because few are unseated (Sabato, 1984; Eismeier and Pollock 1988). Campaign contributions represent a "rational optimizing process" where interests expect favors from those they support (Goddeeris 1989). PACs tend to finance those better able to return campaign favors-incumbents seeking re-election.

An even money strategy involves both parties being approached. This strategy insures that the group's perspective will be heard by the winner even though the eventual victor is unknown and "evens the odds" that the group "wins" should both parties share its position. Finally, the friendly ear approach involves choosing the party sharing the group perspective. Both the social psychology (Thibault and Kelley 1961) and policy process literatures reinforce this motivation. For example, like-mindedness influences in iron triangle relationships (Hamm 1983) and direct legislator-lobbyist interactions (Ziegler and Baer 1969). Shared concerns facilitate mutually șatisfying policymaking relationships (Gais, Peterson and Walker 1984). As economic groups take the "friendly ear" approach in their donor strategy, the platform writing arena should prove no exception. Partisan donations by PACs correspond with the "Friendly Ear" approach as well. 


\section{Economic Interest Group Participation as Symbolic Politics}

Many argue that symbols, in and of themselves, can be far more powerful and meaningful than government allocated tangible resources (Elder and Cobb 1983; Edelman 1964, 1971). Here, the symbolic nature of the interaction between these political actors cannot be overlooked. This scenario is found in other political arenas such as Congress (Truman 1951) and administrative agencies (Nadel 1971).

The democratic nature of the process may similarly appeal to economic groups for testifying and the platform committees for listening. Both parties and economic groups understand that membership mobilization is fostered when organizational leaders testify before the parties because group members are a potential campaign resource.

\section{Hypotheses}

Interest group testimony patterns suggest that the "Power Center" and "Friendly Ear" approaches were more often followed than were the "Even Money" and "Greater Access" strategies (Fine 1994). In 1988, the Republicans received a greater number and wider array of groups than the Democrats.

Labor unions, trade associations and corporations may employ similar strategies. Thus, a greater number of labor groups will testify before the Democrats while more corporations will appear before the Republicans regardless of how circumstances differ between 1988 and 1992.

By contrast, trade association activity may reflect a pragmatic, even money approach because trade groups may believe that particular issues may be too narrow to be reflected in a platform. Communicating with both parties allows trade group concerns to be heard by those who may later affect public policy even though specific concerns may not be reflected in the platform.

Labor unions share the view that collective action benefits membership. Like labor unions, corporations argue that government should support free enterprise. Methods of achieving these ends normally outline business and labor differences. Labor unions may, then, gravitate toward the Democrats because of their traditional pro-labor stance. Corporations may find the Republican party more receptive because of its traditional pro-business orientation.

Finally, most economic groups will support the candidacies of the presidential nominees, either directly or indirectly (i.e., independent 
expenditures), of the party(ies) approached. The similar motivation driving each activity is expected to be manifested behaviorally.

Investigating the nature of economic group testimony during the 1988 and 1992 platform writing processes remains before us. Of particular interest here is the quantity and variety of corporations, trade associations and labor unions appearing. Whether these same groups contributed to the presidential candidacies of the nominees is also questioned. Previous research suggests that economic group electoral and lobbying activities exhibit patterns associated with the interest being represented. Similar approaches may be demonstrated in the platform writing arena.

\section{Methodology}

Each party holds regional hearings during the primary/caucus season so that interested groups and concerned individuals can testify before the platform writing committees. Provided one wants to participate, executive committees do not prescreen witnesses nor does either party bar anyone's testimony. While witnesses must request a place on the schedule, many are invited. The parties may restrict oral remarks (usually to 5-10 minutes). Written materials are also accepted as testimony.

Witnesses representing trade associations, corporations and labor unions were classified by type of group (i.e., educational association, oil company). The Encyclopedia of Associations (1992) provided the principal resource for trade association and labor union classification. Standard and Poors supplied primary corporate interests. Newspapers and magazines also proved useful. Group information was crosstabulated with party audience.

Federal Election Commission records permitted assessment of donor patterns. The criteria for determining group contributions was whether it contributed directly or indirectly (independent expenditure) to the candidate at any point during the election cycle (not just the platform writing season). As support and/or attempts at influencing the process are being examined, narrowing the criteria to either a particular time frame or a direct contribution would likely eliminate several groups from consideration. Because the platform is associated with the nominee (Fishel 1985), contributions to other hopeful nominees candidates were deemed inappropriate in light of the liberal time parameters allowed for contributions in the present analytical framework. A group seeking influence would have likely supported the nominee some time during the election cycle. 
Table 1. Trade Associations Represented in 1988 and 1992, by Party

\begin{tabular}{|c|c|c|c|c|c|c|c|c|}
\hline \multirow[b]{2}{*}{ Professional Concern } & \multicolumn{2}{|c|}{ Democratic } & \multicolumn{2}{|c|}{ Both Parties } & \multicolumn{2}{|c|}{ Republican } & \multicolumn{2}{|c|}{ Total } \\
\hline & 1988 & 1992 & 1998 & 1992 & 1988 & 1992 & 1988 & 1992 \\
\hline Aerospace/Technology & 1 & 4 & 3 & 0 & 4 & 1 & 8 & 5 \\
\hline Building/Realty & 2 & 3 & 3 & 0 & 3 & 0 & 8 & 3 \\
\hline \multicolumn{9}{|l|}{ Education/Community } \\
\hline Service & 1 & 3 & 1 & 0 & 3 & 1 & 5 & 4 \\
\hline \multicolumn{9}{|l|}{ Employment/Labor/ } \\
\hline Pensions & 2 & 2 & 1 & 0 & 2 & 0 & 5 & 2 \\
\hline Ethnicity/Gender & 2 & 0 & 0 & 0 & 2 & 0 & 4 & 0 \\
\hline \multicolumn{9}{|l|}{ Financial/Wholesale/ } \\
\hline Business & 3 & 1 & 0 & 0 & 5 & 6 & 8 & 7 \\
\hline Food/Farming & 0 & 1 & 1 & 0 & 9 & 2 & 10 & 3 \\
\hline Health/Social Welfare & 9 & 7 & 6 & 0 & 3 & 2 & 18 & 9 \\
\hline Law/Law Enforcement & 1 & 1 & 0 & 0 & 2 & 1 & 3 & 2 \\
\hline Manufacturing & 1 & 0 & 1 & 0 & 1 & 0 & 3 & 0 \\
\hline Marine Life/Zoology & 1 & 0 & 0 & 0 & 1 & 0 & 2 & 0 \\
\hline Power/Mining/Metals & 5 & 5 & 1 & 0 & 4 & 4 & 10 & 9 \\
\hline Regulation/Standards & 2 & 0 & 0 & 0 & 3 & 0 & 5 & 0 \\
\hline Transportation/Travel & 0 & 3 & 2 & 0 & 0 & 1 & 2 & 4 \\
\hline Miscellaneous & 1 & 0 & 0 & 0 & 2 & 0 & 3 & 0 \\
\hline Unknown & 2 & 0 & 0 & 0 & 0 & 0 & 2 & 0 \\
\hline Total & 33 & 30 & 19 & 0 & 44 & 18 & 96 & 48 \\
\hline
\end{tabular}

\section{Data Analysis}

Economic interest group participation varied widely between 1988 and 1992. One hundred seventy-eight groups were represented in 1988 whereas seventy-eight testified in 1992. Differences were exhibited within parties and among economic interests. Participation decline may have resulted from the political and partisan disparities between election cycles. Alternatively, the platform writing process itself may have promulgated these differences. Participation within each group type is analyzed and compared across election years.

Trade associations were better represented than either labor unions or corporations during both cycles. Further, more than $20 \%$ of all trade groups testified before both parties in 1988 (See Table 1).

Trade group participation also represents a microcosm of policy concerns dominating the 1988 public agenda. For example, health organizations comprised more than $10 \%$ of all trade groups testifying. Issues such as AIDS, mandatory drug testing of employees and health insurance dominated 
the public mind that year. Health associations also comprised the largest contingent of any trade group type appearing before both parties.

Aerospace/high technology and builders/real estate organization activity suggests that the presidential power center attracted groups sharing similar views. Several of each testified before both parties, a pattern demonstrated by trade associations generally.

Education issues also concerned the public such as merit pay, teacher competency examinations, curricular issues such as sex education, vouchers, and funding inequities within districts and across county lines. Educators' associations gravitated toward the Republican "power center" by a three to one ratio despite education associations traditionally endorsing the Democratic ticket.

Like education associations, agricultural interests exhibited a pragmatic, power centered approach. Of ten food and farming organizations, nine testified before the incumbent party and one addressed both. No agricultural groups spoke with the Democrats only.

A wide array of professional associations appeared before the Republicans and Democrats in 1988. Overall, the Republicans attracted more groups, a finding that reflects PAC behavior favoring incumbents and interest group bias toward the power nexus.

Strong trade association testimony differences were exhibited the following election year. One can conclude from the 1988 patterns that many trade groups testified before both parties because their concerns were too narrow to be included in a platform. Testifying may have been motivated by demonstrating to group members that association concerns were heard by both sides. By comparison, no trade groups appeared before both parties in 1992. Similar patterns were exhibited by the large contingent of health and high technology associations. Energy groups were well represented as well.

The presidential power center was not sought out by most trade associations in 1992. Unlike the prior year, health and educational associations gravitated toward the Democrats. Several factors may explain these differences.

The aforementioned groups may have viewed the Democrats as more receptive because an incumbent presidential party was absent. This possibility is indicated by the lesser number of trade groups participating as well as the shift in distribution: several groups testified before both parties in 1988 whereas trade groups gravitated toward the Democrats in 1992. The Democrats also held one hearing that year in Washington, DC. Those organizations with headquarters there may have found the Democratic audience more convenient.

Lower trade group participation between 1988 and 1992 may also suggest a diminished perception of the importance of platforms. Alternative 
tactics such as lobbying individual candidates and party activists or bringing these group directly to the public may have been deemed wiser investments.

Labor union participation greatly differed from trade association activity. Few labor unions testified before either committee and none appeared before both parties in 1988 (Table 2). The Democrats comprised the sole audience in 1992. These small quantities (six witnesses in 1988; eight in 1992) preclude generalizing labor union testimony.

Two possibilities may explain the comparatively low labor union participation. Labor perspectives may be well known to both parties making testimony appear unproductive compared with alternative approaches. Union testimony was the least participatory either year under examination despite the change in electoral circumstances that may have influenced trade association activity.

Corporation activity reflected corporate PAC behavior both years as the power center and friendly ear approaches dominated their involvement. The data summarized in Table 3 show that nearly $70 \%$ of all businesses represented testified before the Republicans only in 1988 and over half did the same in 1992. Certain industries whose interests are often addressed in platforms participated more than those that are not.

No single type of corporation dominated business involvement although energy companies and high technology industries were most prevalent. More than $15 \%$ among corporate group represented energy companies in 1988; over one third in 1992. One would expect higher participation within an industry whose concerns greatly influence domestic and international politics.

More than $10 \%$ of all corporate participants represented aerospace and high technology. Technological policy considerations, particularly as they applied to the Strategic Defense Initiative, offer a primary reason for selecting a Republican audience in 1988. Efforts toward reducing defense spending and enjoying a "peace dividend" increased by 1992 due to political changes in Eastern Europe, the former Soviet Union and Germany. Aerospace and high technology industries may have believed that neither party would be receptive that year. Finally, investment banks showed a stronger presence than other industries in 1988. Little activity was exhibited the following election year.

Corporate witnesses showed a clear Republican bias in 1988 and a participatory decline in 1992 . The pro-business stance traditionally communicated in Republican platforms makes this decline surprising. Nonetheless, business interests taking the pragmatic approach by communicating with the Republicans found a friendly ear at the power center. 
Table 2. Labor Unions Represented in 1988 and 1992, by Party

\begin{tabular}{lcccccccc}
\hline & \multicolumn{2}{c}{ Democratic } & \multicolumn{2}{c}{ Both Parties } & \multicolumn{2}{c}{ Republican } & \multicolumn{2}{c}{ Total } \\
Type of Union & 1988 & 1992 & 1998 & 1992 & 1988 & 1992 & 1988 & 1992 \\
\hline Builder & 1 & 0 & 0 & 0 & 0 & 0 & 1 & 0 \\
Education & 1 & 1 & 0 & 0 & 0 & 0 & 1 & 1 \\
Electric & 0 & 0 & 0 & 0 & 1 & 0 & 1 & 0 \\
Employment/Labor & 1 & 3 & 0 & 0 & 2 & 0 & 3 & 3 \\
Food & 0 & 1 & 0 & 0 & 0 & 0 & 0 & 1 \\
Garments & 0 & 1 & 0 & 0 & 0 & 0 & 0 & 1 \\
Steel & 0 & 1 & 0 & 0 & 0 & 0 & 0 & 1 \\
Treasury & 0 & 1 & 0 & 0 & 0 & 0 & 0 & 1 \\
Total & 3 & 4 & 0 & 0 & 3 & 0 & 6 & 8 \\
\hline
\end{tabular}

Table 3. Corporations Represented in 1988 and 1992, by Party

\begin{tabular}{|c|c|c|c|c|c|c|c|c|}
\hline \multirow[b]{2}{*}{ Professional Concern } & \multicolumn{2}{|c|}{ Democratic } & \multicolumn{2}{|c|}{ Both Parties } & \multicolumn{2}{|c|}{ Republican } & \multicolumn{2}{|c|}{ Total } \\
\hline & 1988 & 1992 & 1998 & 1992 & 1988 & 1992 & 1988 & 1992 \\
\hline \multicolumn{9}{|l|}{ Aerospace/ } \\
\hline High Technology & 1 & 1 & 0 & 0 & 9 & 1 & 10 & 2 \\
\hline Business & 3 & 4 & 2 & 0 & 11 & 0 & $16^{\mathrm{a}}$ & 4 \\
\hline Financial/Consumers & 2 & 0 & 2 & 0 & 7 & 2 & 11 & 2 \\
\hline Food/Farming & 1 & 0 & 0 & 0 & 4 & 1 & 5 & 1 \\
\hline International & 1 & 0 & 0 & 0 & 2 & 0 & 3 & 0 \\
\hline Law & 0 & 1 & 0 & 0 & 0 & 0 & 0 & 1 \\
\hline Lumber & 0 & 0 & 0 & 0 & 1 & 0 & 1 & 0 \\
\hline Medical/Dental & 0 & 0 & 0 & 0 & 4 & 1 & 4 & 1 \\
\hline Metals/Mining & 2 & 0 & 1 & 0 & 1 & 1 & 4 & 1 \\
\hline Pensions/Retirement & 1 & 0 & 0 & 0 & 0 & 0 & 1 & 0 \\
\hline Policy Studies & 2 & 0 & 0 & 0 & 0 & 0 & 2 & 0 \\
\hline Power/Energy & 1 & 3 & 5 & 0 & 7 & 5 & 13 & 8 \\
\hline Publishing & 0 & 0 & 0 & 0 & 1 & 0 & 1 & 0 \\
\hline Recreation/Entertainment & 0 & 1 & 0 & 0 & 1 & 0 & 1 & 1 \\
\hline Transportation & 0 & 0 & 0 & 0 & 2 & 1 & 2 & 1 \\
\hline Total & 14 & 10 & 10 & 0 & 50 & 12 & 74 & 22 \\
\hline
\end{tabular}

${ }^{\text {a }}$ The products of these businesses were not available through Standard and Poors, newspapers or magazines. 
Economic group testimony does not demonstrate one general pattern within group types or across election years. One might expect that the shared economic concerns among these groups would be manifested in comparable appearance patterns. Such is not the case. Trade associations dominated economic group participation whereas labor unions were generally inactive. Business interests showed a strong Republican preference in 1988 and reasonably equal interest in both parties the following year.

The participatory decline among trade and corporate groups may be explained by a growing perception that platforms are less effective campaign guides and policy tools in an era dominated by candidate centered elections, split ticket voting and increasing independent identification, all indicators of decreasing partisan reliance at the mass and elite levels (Fiorina 1990). As a consequence, group testimony may be perceived as an activity with advantages beyond influencing party policy such as constituent service and reinforcing group presence and views through all available forums.

Comparing testimony patterns with PAC contribution behavior is warranted because one can then assess whether those economic groups who testified also utilized more traditional persuasion techniques. Alternatively, different groups may engage in different activities.

Table 4 shows that the latter is evident here. Few economic groups both contributed and testified in 1988 and 1992, an unexpected finding in light of the similar motivations of each behavior. While over one hundred economic groups appeared each year, few contributed money to either presidential candidate. In sum, those giving advice did not give money.

Economic groups exhibited a dichotomous strategy. Those who gave money rarely testified while those appearing were less inclined to make financial contributions. Alternatively, those who testified may have utilized other paths of influence such as securing delegate slots for their members or giving money to congressional candidates. In so doing, a multifaceted approach to electoral participation could be achieved.

The findings presented here show that audience selection parallels both PAC contribution strategies and interest group testimony patterns. Issues that are often emphasized in platforms were addressed through the organized efforts of outside groups demonstrating symbolic linkages.

\section{Conclusion}

Economic interests bring a wide constellation of issues to the platform writing arena. Their participation is particularly intriguing because political parties traditionally address economic issues in their platforms. Economic groups speak to popular issues when addressing the platform writing 


\section{Table 4. Witness Making Financial Contributions, 1988 and 1992 by Party}

\begin{tabular}{llccc}
\hline Recipient $^{\mathrm{a}}$ & Democratic & Both Parties & Republican \\
\hline 1988 Bush & 1 & 2 & 10 \\
& Dukakis & 5 & 1 & 1 \\
1992 Bush & 0 & 0 & 0 \\
& Clinton & 2 & 0 & 0
\end{tabular}

${ }^{a}$ No economic group that testified contributed money to both candidates.

committees. Participating in the framing of a document that may later guide policy also serves economic group goals.

Research exploring economic group participation in political campaigns has focused on endorsements, financial contributions and independent expenditures (Malbin 1984). Speculation that corporate, trade association and labor union activity has fostered both party decline and candidate individualism has also arisen because economic groups perform many of the same campaign functions that parties do (Orren and Mayer 1990). Save for anecdotal reports (Greenwald 1979), economic interest group testimony before the platform writing committees has heretofore remained unexplored.

The present endeavor broadens our understanding of economic group participation in electoral politics. Similar motivations do not foster similar actions among economic groups. Testifying before the platform writing committees reflects better known political strategies although the same organizations do not engage in both activities. The symbolic nature of the platform writing process is also demonstrated in that both sides of the interaction may earn positive public regard for their participation even in the absence of a direct association between group testimony and platform planks.

\section{NOTES}

The author wishes to thank three anonymous reviewers for their comments on an earlier draft of this manuscript. An earlier version of the paper was presented at the 1992 American Political Science Association Annual Meeting. The author gratefully acknowledges the research assistance of Christine Redmond and wishes to thank Richard Boylan of the Democratic National Committee and Patricia Giardina of the Republican National Committee for their patient assistance. These data would have been impossible to obtain without their help. Research support was provided by the University of Central Florida Division of Sponsored Research In-House Award \#11-80-920. 
${ }^{1}$ Similarly, see Pomper and Lederman (1980) who discuss the difficulty with demonstrating that platform planks become a party's legislative agenda even though consistency may exist between them.

${ }^{2}$ This does not suggest that George Bush was ahead in the polls throughout the 1988 and 1992 campaign seasons. While incumbency brings advantages such as a record and name recognition, opposition strategists may use that information to create a negative "spin" resulting in popularity and electoral expectation fluctuations.

\section{REFERENCES}

Budge, Ian and Richard I. Hofferbert. 1990. Mandates and Policy Outputs: U.S. Party Platforms and Federal Expenditures. American Political Science Review 84:111131.

Burek, Deborah M., ed. 1992. Encyclopedia of Associations. 26th ed.; Detroit, MI: Gale Research Inc.

Burris, Val. 1987. The Political Partisanship of American Business: A Study of Corporate Political Action Committees. American Sociological Review 52:732-44. Cigler, Allan J. and Burdett A. Loomis, eds. 1986. Interest Group Politics 2nd ed. Washington, DC: Congressional Quarterly Press.

Edelman, Murray. 1964. The Symbolic Uses of Politics. Urbana: University of Illinois Press.

1971. Politics as Symbolic Action: Mass Arousal and Quiescence. New York: Academic Press.

Eismeier, Theodore J. and Philip H. Pollock III. 1988. Business, Money and the Rise of Corporate PACs in American Elections. New York, NY: Quorum Books.

Elder, Charles D. and Roger W. Cobb. 1983. The Political Uses of Symbols. New York: Longman.

Fine, Terri Susan. 1991. National Party Platforms and Platform Writing. In L. Sandy Maisel, ed., Encyclopedia of American Political Parties and Elections. New York: Garland. 26:517-30.

1994. Interest Groups and the Framing of the 1988 Party Platforms. Polity

Fiorina, Morris. 1990. The Electorate in the Voting Booth. In L. Sandy Maisel, ed. The Parties Respond: Changes in the American Party System. Boulder, CO: Westview Press.

Fishel, Jeffrey. 1985. Presidents and Promises: From Campaign Pledge to Presidential Performance. Washington, DC: CQ Press.

Frantzich, Stephen. 1989. Political Parties in a Technological Age. New York: Longman.

Gais, Thomas, Mark Peterson and Jack Walker. 1984. Interest Groups, Iron Triangles and Representative Institutions in American National Government. British Journal of Political Science 14:161-185.

Goddeeris, John. 1989. Modeling Interest Group Campaign Contributions. Public Finance Quarterly 17(2):158-184. 
Green, John C. and James L. Guth. 1986. Big Bucks and Petty Cash: Party and Interest Group Activists in American Politics. In Allan J. Cigler and Burdett A. Loomis, eds. Interest Group Politics. 2nd ed.; Washington, DC: CQ Press.

Greenwald, Carol. 1979. Group Power: Lobbying and Public Policy. New York: Praeger. Hamm, Keith E. 1983. Patterns of Influence Among Committees, Agencies, and Interest Groups. Legislative Studies Quarterly 8:379-427.

Handler, Edward and John R. Mulkern. 1982. Business in Politics: Campaign Strategies of Corporate Political Action Committees. Lexington, MA: D.C. Heath.

Herndon, James F. 1982. Access, Record and Competition as Influences on Interest Group Contributions to Congressional Campaigns. Journal of Politics 44:996-1019.

Hetzner III, C.N. and Stu Westin. 1987. Legislative Ratings as a Metric of Goal Cohesion within Interest Groups: Business vs. Labor. Public Choice 53(1):21-39. Lindblom, Charles. 1977. Politics and Markets: The World's Political Economic Systems. New York: Basic Books.

Maisel, L. Sandy, ed. 1990. The Parties Respond: Changes in the American Party System. Boulder, CO: Westview Press.

Malbin, Michael J., ed. 1984. Money and Politics in the United States. Chatham, NJ: Chatham House.

Nadel, Mark. 1971. The Politics of Consumer Protection. Indianapolis: Bobbs-Merrill. Orren, Gary R. and William G. Mayer. 1990. The Press, Political Parties, and the Public-Private Balance in Elections. In L. Sandy Maisel, ed., The Parties Respond: Changes in the American Party System. Boulder, CO: Westview Press.

Parris, Judith. 1972. The Convention Problem: Issues in Reform of Presidential Nominating Procedures. Washington, DC: Brookings Institution.

Pomper, Gerald and Susan Lederman. 1980. Elections in America: Control and Influence in Democratic Politics. 2nd ed.; New York: Longman.

Sabato, Larry J. 1984. PAC Power: Inside the World of Political Action Committees. New York: Norton.

Shea, Maureen and Ellen Miller. 1989. PACs on PACs: The View from the Inside. Center for Responsive Politics, Washington, DC.

Thibault, John and Harold Kelley. 1961. The Social Psychology of Groups. New York: John Wiley.

Truman, David. 1951. The Governmental Process. New York: Knopf.

Wilhite, Allen and John Theilmann. 1987. Labor PAC Contributions and Labor Legislation: A Simultaneous Logit Approach. Public Choice 53(3):267-276.

Ziegler, L. Harmon and Michael Baer. 1969. Lobbying: Interaction and Influence in American State Legislatures. Belmont, CA: Wadsworth. 